Apidologie, 1986, 17 (1), 33-48

\title{
FIELD AND SIMPLIFIED TECHNIQUES FOR IDENTIFYING AFRICANIZED AND EUROPEAN HONEY BEES
}

\author{
Thomas E. RINDERER, H. Allen SYLVESTER, Michael A. BROWN, \\ Jose D. VILLA, Daniel PESANTE and Anita M. COLlINS \\ with the technical collaboration of \\ Robert SPENCER, Sandra KLEINPETER and Vicki LANCASTER \\ United States Department of Agriculture, Agricultural Research Service \\ Honey Bee Breeding, Genetics \& Physiology Research \\ 1157 Ben Hur Rd., Baton Rouge, LA 70820, U.S.A.
}

\begin{abstract}
SUMMARY
In the Americas, almost all colonies of Africanized and European honey bees that are building their own comb can be identified in the field, by measuring the distance spanned by 10 worker cells. Discriminant analysis of worker bee morphometric characteristics can be used to identify bees which are not producing their own comb. The simplest analysis uses measurements of fore-wing length and correctly identified $86 \%(P>0.90)$ of 86 Africanized and 50 European colonies, with no misidentifications. A multivariate analysis of fore-wing length, partial hind-wing length, femur length and «clean weight», correctly identified $91 \%(\mathrm{P}>0.90)$ of these samples, with no misidentifications. The formulae, constants and procedures for these analyses are provided.
\end{abstract}

\section{INTRODUCTION}

The continued spread of Africanized bees in the Americas (recently reviewed by STIBICK, 1984) has lead to a desire within the apicultural community to have accurate and rapid methods to discriminate between Africanized and European honey bees. A quality method, based on the discriminant analysis of 25 morphometric characters, has been available for some time (DALY and BALLING, 1978). This method is expensive and time consuming despite the more recent use of computer-assisted measurement (DALY et al., 1982). The computerization and technical difficulties of the methods developed by DALY and BaLling (1978) and DALY et al. (1982) restrict their use to well-equipped laboratories having trained personnel. This is also true of a newer discriminant analysis (DALY and Hoelmer, 1985) and the potential uses of gas chromatography (CARLSON and Bolten, 1984) and electrophoresis (Sylvester, 1982). The newer discriminant analysis (DAlY and HoElmer, 1985) uses computer-assisted measurements of 47 
fore-wing characteristics. Because only fore wings are used, it reduces dissection time. However, it has an increased number of measurements which require computer assistance for measurement and calculation. This second method is an excellent «first-step》 procedure for an identification laboratory since it will unambiguously and correctly identify $99 \%$ of unknown samples. The remaining $1 \%$ (ambiguous samples) can be identified by the more elaborate 1982 procedure.

The costs and technical requirements of the identification procedures developed by DALY and his colleagues prohibit the wide scale routine evaluation of apiaries. Apiculturalists and regulatory agencies in several countries require field and less complex liboratory procedures which will rapidly identify large numbers of samples. This paper describes a series of simplified techniques which will correctly identify most samples from Africanized and European colonies. The identification of the remaining samples is ambiguous. Such samples will be sufficiently few that laboratories using the more elaborate techniques will likely be able to process them in support of large-scale surveys and regulatory activities.

\section{FIELD IDENTIFICATION}

No behavioral or morphological characteristic of Africanized bees is sufficiently different to guide the inexperienced collector to correct field identifications. However, when identifications are desired for feral or other colonies which have produced worker comb without benefit of foundation, most colonies can be easily identified.

RINDERI:R et al. (1982) found that single measurements of the distance spanned by 10 European cells ranged from 5.0 to $5.5 \mathrm{~cm}$. Averages of 3 measures ranged from $5.2 \pm 0.02(\mathrm{X} \pm \mathrm{SE})$ to $5.3 \pm 0.02 \mathrm{~cm}$. In contrast, single measurements of the distance spanned by 10 Africanized cells ranged from 4.5 to $5.0 \mathrm{~cm}$. Averages of 3 measures ranged from $4.8 \pm 0.02$ to $4.9 \pm 0.02 \mathrm{~cm}$.

Based on this study, colonies producing worker comb having an average of 3 measurements of $4.9 \mathrm{~cm}$ or below have a probability of being Africanized of 1.0. Colonies producing worker comb having an average of 3 measurements of $5.2 \mathrm{~cm}$ or above have a probability of being European of 1.0. We have encountered a few colonies which had intermediate values. If others are found they should be considered unidentifiable by this procedure, but suspected to be Africanized to some extent. For this procedure each cell is interpreted to have one cell wall. The outside of the wall of the first cell is included in the measure. The last cell is measured up to the edge of the eleventh wall. Only fully formed worker cells in the central portion of a comb should be measured. 


\section{DEVELOPMENT OF SIMPLIFIED DISCRIMINANT ANALYSES}

\section{Materials and Methods}

A collection of 30 bees was made from each of 86 Africanized and 50 Euronean colonies in apiaries near Sarare, Venezuela. Both geographical types of bees 1 were from managed colonies having comb produced from European-sized foundation. This causes Africanized bees to have slightly larger body measurements (Rinderer et al., 1985 a) and is typical of the conditions of many identification needs. For collections, colony entrances were blocked, returning foraging bees were collected, and the samples were frozen for preliminary processing. Within three days, the bees were thawed, their pollen pellets were removed, their nectar loads were expelled (GARY and LORENZEN, 1976) and their rectal contents were removed by applying gentle pressure on the abdomens. Three groups of 10 bees from each colony were weighed («clean weights 》) to the nearest $0.01 \mathrm{~g}$. The samples were then stored in alcohol for later processing.

One sample of 10 bees from each colony was analyzed morphometrically by the process of Daly et al. (1982). This analysis both verified the field identification of the bees and provided measurements of selected body parts. Clean weights, fore-wing lengths, partial hind-wing lengths, hind-wing widths and femur lengths were chosen for statistical analysis. Clean weights were chosen because they are easily obtained, are significantly different for bees from Africanized and European colonies (Rinderer et al., 1985 a) and are distinctly different for bees from swarms of Africanized and European colonies where at least the Africanized swarms probably originated from feral colonies (RINDERER $e t$ al., 1982). The other measurements were chosen because they are relativity easy to obtain and are major factors in the discriminant analysis of DALY and BALLING (1978). The data consisted of 3 replicate measures of clean weight per colony and 10 replicate measures, from each of 10 bees, for the other characters. The date were analyzed with a (SAS@2, 1982) «stepwise" discriminant analysis procedure. This procedure selects the single best discriminating character, the two best discriminating characters in combination, the thee best discriminating characters in combination, etc. Discriminant functions were then developed using variables suggested by the stepwise procedure.

This paper uses the convention, unlike the $\mathrm{SAS} \otimes$ procedure, of an unidentified category. A sample not having a high probability of membership in either group is assigned to the unidentified category. Correct identifications are defined as those that are classified in their correct group at $P>0.90$ while misidentifications are those samples that are classified in the incorrect group at $P>0.90$. The unidentified category is useful in this context since more elaborate procedures (DALY et al., Loc. Cit.) exist to more closely examine samples which remain unidentified.

\section{Results}

The single character which best discriminated between Africanized and European bees was fore-wing length (Table 1). With the criterion that the pro-

(1) The European honeybees in this study were from North America. Such bees have in their ancestry representives of mixed subspecies. Africanized bees are descendants of A.m. scutellata bees imported flom Afrca and their hybrids with various subspecies previously imported into Brazil. Neither the European nor the Africanized bees can correctly be called race, subspecies, stock, or line representatives. We use the term «geographical type» to indicate that the bees we studied showed major characteristics typical of descriptions for temperately or tropically (A.m. scutellata) adapted bees.

(2) SAS Institute, Inc., Cary, North Carolina. Use of a corporation name does not constitute an endorsement by the U.S. Dept. of Agriculture. 
bability of group membership exceed $0.90(\mathrm{P}>0.90) 109$ or $86 \%$ of the samples were correctly identified. No samples were misidentified : the remaining samples were unidentified by the procedure. The two closest cases of misidentifying Africanized bees as European had probabilities of being European of 0.86 and 0.65 . The two closest cases of misidentifying European bees as Africanized had probabilities of being Africanized of 0.70 and 0.64 . At $\mathrm{P}>0.95$ and $\mathrm{P}>0.99$ the procedure correctly identified 69 and $52 \%$ of the samples, respectively (Table 1).

TABL. 1. - Number (and percentage) of Africanized (A) and European (E) bees

of a base-line collection from $86 \mathrm{~A}$ and $50 \mathrm{E}$ colonies identified post priori as $A, E$, or unclassifiable $(U)$ by two discriminant analysis procedures for 3 levels of probability of classification

\begin{tabular}{|c|c|c|c|c|c|c|c|}
\hline \multirow{2}{*}{$\begin{array}{c}\text { Probability } \\
\text { of } \\
\text { classification }\end{array}$} & \multirow{2}{*}{$\begin{array}{l}\text { Actual } \\
\text { bee } \\
\text { type }\end{array}$} & \multicolumn{3}{|c|}{$\begin{array}{l}\text { Classification } \\
\text { by fore-wing procedure }\end{array}$} & \multicolumn{3}{|c|}{$\begin{array}{l}\text { Classification } \\
\text { by multivariate procedure }\end{array}$} \\
\hline & & A & $\mathbf{E}$ & $\mathbf{U}$ & A & $\mathbf{E}$ & $\mathbf{U}$ \\
\hline \multirow[t]{2}{*}{0.90} & A & $69(80.2)$ & $0 \quad(0.0)$ & $17(19.8)$ & $79(91.9)$ & $0 \quad(0.0)$ & $7(8.1)$ \\
\hline & $\mathbf{E}$ & $0 \quad(0.0)$ & $40(80.0)$ & $10(20.0)$ & $0 \quad(0.0)$ & $45(90.0)$ & $5(10.0)$ \\
\hline \multirow[t]{2}{*}{0.95} & A & $59(68.6)$ & $0 \quad(0.0)$ & $27(31.4)$ & $74(86.0)$ & $0 \quad(0.0)$ & $12(14.0)$ \\
\hline & $\mathrm{E}$ & $0 \quad(0.0)$ & $35(70.0)$ & $15(30.0)$ & $0 \quad(0.0)$ & $45(90.0)$ & $5(10.0)$ \\
\hline \multirow[t]{2}{*}{0.99} & A & $44(51.2)$ & $0 \quad(0.0)$ & $42(48.8)$ & $59(68.6)$ & $0 \quad(0.0)$ & $27(31.4)$ \\
\hline & $\mathrm{E}$ & $0 \quad(0.0)$ & $27(54.0)$ & $23(46.0)$ & $0(0.0)$ & $37(74.0)$ & $13(26.0)$ \\
\hline
\end{tabular}

The calculations for the discriminant analysis of fore-wing length are straightforward. The average of the fore-wing lengths $(\bar{X})$ is first calculated. Two values $\left(D_{A}^{2}\right.$ and $\left.D_{E}^{2}\right)$ are then calculated from $\bar{X}, 8.87$ (the overall average forewing length of Africanized bees), 9.20 (the overall average fore-wing length of European bees) and a discriminant coefficient of 0.01341759 as follows :

$$
\begin{aligned}
& \mathrm{D}_{\mathrm{A}}^{2}=(\overline{\mathrm{X}}-8.87)^{2} / 0.01341759 \\
& \text { and } \\
& \mathrm{D}_{\mathrm{E}}^{2}=(\overline{\mathrm{X}}-9.20)^{2} / 0.01341759
\end{aligned}
$$

The probability that the sample is Africanized $(P A)$ is :

$$
\mathrm{PA}=\mathrm{e}^{-0.5 * \mathrm{D}_{\mathrm{A}}^{2}} /\left(\mathrm{e}^{-0.5^{*} \mathrm{D}_{\mathrm{A}}^{2}}+\mathrm{e}^{-0.5^{*} \mathrm{D}_{\mathrm{F}}^{2}}\right)
$$

The probability that the sample is European $(P E)$ is :

$$
\mathrm{PE}=1-\mathrm{PA}
$$


TABL. 2. - Fore-wing length means $(\hat{X})$ of 10 bees and corresponding probabilities of their being Africanized (PA) or European (PE)

\begin{tabular}{|c|c|c|c|c|c|}
\hline$\overline{\mathbf{X}}$ & PE & PA & $\mathbf{x}$ & PE & PA \\
\hline 8.770 & .001 & .999 & 9.035 & .500 & .500 \\
\hline 8.775 & .002 & .998 & 9.040 & .531 & .469 \\
\hline 8.780 & .002 & .998 & 9.045 & .561 & .439 \\
\hline 8.785 & .002 & .998 & 9.050 & .591 & .409 \\
\hline 8.790 & .002 & .998 & 9.055 & .621 & .379 \\
\hline 8.795 & .003 & .997 & 9.060 & .649 & .351 \\
\hline 8.800 & .003 & .997 & 9.065 & .677 & .323 \\
\hline 8.805 & .003 & .997 & 9.070 & .703 & .297 \\
\hline 8.810 & .004 & .996 & 9.075 & .728 & .272 \\
\hline 8.815 & .004 & .996 & 9.080 & .752 & .248 \\
\hline 8.820 & .005 & .995 & 9.085 & .774 & .226 \\
\hline 8.825 & .006 & .994 & 9.090 & .795 & .205 \\
\hline 8.830 & .006 & .994 & 9.095 & .814 & .186 \\
\hline 8.835 & .007 & .993 & 9.100 & .832 & .168 \\
\hline 8.840 & .008 & .992 & 9.105 & .848 & .152 \\
\hline 8.845 & .009 & .991 & 9.110 & .863 & .137 \\
\hline 8.850 & .010 & .990 & 9.115 & .877 & .123 \\
\hline 8.855 & .012 & .988 & 9.120 & .890 & .110 \\
\hline 8.860 & .013 & .987 & 9.125 & .901 & .099 \\
\hline 8.865 & .015 & .985 & 9.130 & .912 & .088 \\
\hline 8.870 & .017 & .983 & 9.135 & .921 & .079 \\
\hline 8.875 & .019 & .981 & 9.140 & .930 & .070 \\
\hline 8.880 & .022 & .978 & 9.145 & .937 & .063 \\
\hline 8.885 & .024 & .976 & 9.150 & .944 & .056 \\
\hline 8.890 & .027 & .973 & 9.155 & .950 & .050 \\
\hline 8.895 & .031 & .969 & 9.160 & .956 & .044 \\
\hline 8.900 & .035 & .965 & 9.165 & .961 & .039 \\
\hline 8.905 & .039 & .961 & 9.170 & .965 & .035 \\
\hline 8.910 & .044 & .956 & 9.175 & .969 & .031 \\
\hline 8.915 & .050 & .950 & 9.180 & .975 & .027 \\
\hline 8.920 & .056 & .944 & 9.185 & .976 & .024 \\
\hline 8.925 & .063 & .937 & 9.190 & .978 & .023 \\
\hline 8.930 & .070 & .923 & 9.195 & .981 & .019 \\
\hline 8.935 & .079 & .921 & 9.200 & .983 & .017 \\
\hline 8.940 & .088 & .912 & 9.205 & .985 & .015 \\
\hline 8.945 & .099 & .901 & 9.210 & .987 & .013 \\
\hline 8.950 & .110 & .890 & 9.215 & .988 & .012 \\
\hline 8.955 & .123 & .877 & 9.220 & .990 & .010 \\
\hline 8.960 & .137 & .863 & 9.225 & .991 & .009 \\
\hline 8.965 & .152 & .848 & 9.230 & .992 & .008 \\
\hline 8.970 & .168 & .832 & 9.235 & .993 & .007 \\
\hline 8.975 & .186 & .814 & 9.240 & .994 & .006 \\
\hline 8.980 & .205 & .795 & 9.245 & .994 & .006 \\
\hline 8.985 & .226 & .778 & 9.250 & .995 & .005 \\
\hline 8.990 & .248 & .752 & 9.255 & .996 & .004 \\
\hline 8.995 & .272 & .728 & 9.260 & .996 & .004 \\
\hline 9.000 & .297 & .703 & 9.265 & .997 & .003 \\
\hline 9.005 & .323 & .677 & 9.270 & .997 & .003 \\
\hline 9.010 & .351 & .649 & 9.275 & .997 & .003 \\
\hline 9.015 & .379 & .621 & 9.280 & .998 & .002 \\
\hline 9.020 & .409 & .591 & 9.285 & .998 & .002 \\
\hline 9.025 & .439 & .561 & 9.290 & .998 & .002 \\
\hline \multirow[t]{2}{*}{9.230} & .469 & .531 & 9.295 & .998 & .002 \\
\hline & & & 9.300 & .999 & .001 \\
\hline
\end{tabular}


Table 2 provides conversions from average fore-wing length measurements $(\bar{X})$ to $P A$ and $P E$ for the range of $P A=0.99$ to $P E=0.99$.

Generally, substantial improvements in discriminatory power occurred as more characteristics were added to the analysis. The width of the hind-wing did not strongly improve discrimination. Thus, the best multivariate set was based on measurements of fore-wing length, clean weight, partial hind-wing length and femur length.

With this analysis, $91 \%$ of the samples were correctly identified at $\mathrm{P}>0.90$ (Table 1). No samples were misidentified : the remaining samples remained unidentified. The closest misidentification of a European colony had a $P A$ of 0.72 and the closest misidentification of an Africanized colony had a $P E$ of 0.76 . The calculations for the multivariate discriminant analysis are somewhat complex and probably best done with the aid of at least a small programmable calculator. Several constants are required in the calculations. They and their abbreviations are provided in Table 3.

TABL. 3. - Average body-part measturements and discriminant-analysis coefficients used in the multivariate, morphometric analysis of Africanized and European honey bees

\begin{tabular}{|c|c|}
\hline Average body part measurements & Discriminant-analysis coefficients \\
\hline Fore-wing lengths & $C 11=204.49800$ \\
\hline Africanized $=A F W=8.864400$ & $C 21=-\quad 1.56593$ \\
\hline European $=E F W=9.197601$ & $C 3 I=-229.64500$ \\
\hline & $C 41=-98.95020$ \\
\hline Clean weights & $C 12=-1.56593$ \\
\hline Africanized $=A C=0.7495$ & $C 22=116.50100$ \\
\hline \multirow[t]{2}{*}{ European $=E C=0.9196$} & $C 32=-23.79970$ \\
\hline & 14.22020 \\
\hline Partial hind-wing lengths & $C 13=-229.6450$ \\
\hline Africanized $=A H=4.2010$ & $C 23=-23.7997$ \\
\hline \multirow[t]{2}{*}{ European $=E H=4.3167$} & $C 33=499.3310$ \\
\hline & $C 43=-59.2050$ \\
\hline Femur lengths & $C 14=-98.9502$ \\
\hline Africanized $=A F E=2.5298$ & $C 24=14.2202$ \\
\hline \multirow[t]{2}{*}{ European $=E F E=2.6200$} & $C 34=-59.2050$ \\
\hline & $C 44=678.9840$ \\
\hline
\end{tabular}

The procedure is developed for 3 measurements of clean weights and 10 measurements of fore-wing lengths, partial hind-wing lengths and femur lengths. After measurements, the average values, $X C, X F W, X H$ and $X F E$, respectively, are calculated. 
The differences between these values and the average values for Africanized bees are then found : $A X 1=X F W-A F W, A X 2=X C-A C, A X 3=$ $X H-A H$ and $A X 4=X F E-A F E$. These differences and the elements of the inverse pooled variance - covariance matrix are then used to calculate the multivariate $D_{A}^{\ddot{2}}$ :

$$
\begin{aligned}
& \{[(\mathrm{AX} 1 * \mathrm{C} 11)+(\mathrm{AX} 2 * \mathrm{C} 21)+(\mathrm{AX} 3 * \mathrm{C} 31)+(\mathrm{AX} 4 * \mathrm{C} 41)] * \mathrm{AX} 1\}+ \\
& \{[(\mathrm{AX} 1 * \mathrm{C} 12)+(\mathrm{AX} 2 * \mathrm{C} 22)+(\mathrm{AX} 3 * \mathrm{C} 32)+(\mathrm{AX} 4 * \mathrm{C} 42)] * \mathrm{AX} 2\}+ \\
& \{[(\mathrm{AX} 1 * \mathrm{C} 13)+(\mathrm{AX} 2 * \mathrm{C} 23)+(\mathrm{AX} 3 * \mathrm{C} 33)+(\mathrm{AX} 4 * \mathrm{C} 43)] * \mathrm{AX} 3\}+ \\
& \{[(\mathrm{AX} 1 * \mathrm{C} 14)+(\mathrm{AX} 2 * \mathrm{C} 24)+(\mathrm{AX} 3 * \mathrm{C} 34)+(\mathrm{AX} 4 * \mathrm{C} 44)] * \mathrm{AX} 4\}
\end{aligned}
$$

The same procedures are followed with the average European values : $E X 1=X F W-E F W, E X 2=X C-E C, E X 3=X H-E H$ and $E X 4=$ $X F E-E F E . D_{E}^{2}$ is calculated by substituting $E X 1, E X 2, E X 3$ and $E X 4$ for $A X 1, A X 2, A X 3$ and $A X 4$ in Eq. 5.

$P A$ and $P E$ are calculated from $D_{A}^{2}$ and $D_{E}^{2}$ according to Eqs. 3 and 4.

\section{TESTING OF SIMPLIFIED DISCRIMINANT ANALYSES}

\section{Materials and Methods}

In order to evaluate both the discriminant procedures and simplified methods of measurement, we collected bees from a second, independent group of 50 Africanized and 50 European colonies. All Africanized bees again came from colonies in Venezuela having combs produced from European foundation. European bees were collected from 5 colonies in Venezuela and 45 in Louisiana.

Bees collected in Venezuela were prepared, weighed (clean weights) and placed in alcohol as before. Bees collected in Louisiana were prepared, weighed, and dissected without storage in alcohol.

Bees were dissected for measurement by removing the two left wings and the right femur. The wings were removed with fingers or forceps as near to the thorax as possible. The right leg was first removed by breaking the joint between the coxa and the thorax. The coxa and trochanter were then removed from the proximal end of the femur. This process was accomplished by grasping the trochanter with fine forceps and gently pulling it away from the femur without bending the joint. Some persons doing this required a hand lens to check that they did not remove part of the femur, others could see well enough to verify the quality of dissection without magnification. In some cases this dissection was easier with bees that had not been in alcohol and had not been permitted to dry. Thus, fresh bees are preferred but not essential for this dissection.

A large $(22 \times 40 \mathrm{~mm}$; \# 1 thickness $)$, standard, glass cover slip was connected, with a small piece of transparent tape at one end, to a smaller $(22 \times 22 \mathrm{~mm}$; \# 1) cover slip. This tape formed a hinge between the two cover slips. The wings were placed and straightened on the portion of the larger cover slip so that they would be held by the smaller one when the cover slips were folded together. Consistent placement of the wings facilitated measurements. The smaller cover slip was folded over the wings and held in place by hand. The dissected portions of the leg were placed on the larger cover slip close to the edge of the smaller cover slip. The joint of the leg between the 
femur and the tibia was bent to a closed position to facilitate measurement. A small piece of transparent tape was placed over the leg and at the same time over the edge of the smaller cover slip to hold them in place.

For record-keeping purposes, a small label was placed on the remaining portion of the larger cover slip and appropriately labeled. Slides were coded such that the identification of the bees was unknown to those making measurements. The subassembly of cover slips and body parts was placed in a standard $35 \mathrm{~mm}$ plastic photographic slide mount designed with an opening through which slides could be inserted (Fig. 1).

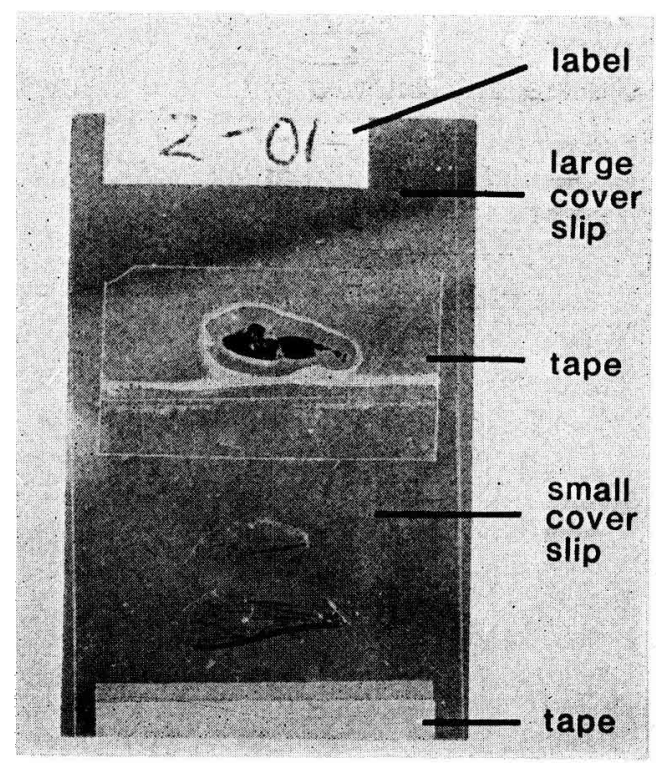

FIG. 1. - The assembly of body parts, cover slips, tape, and label in a slide mount ready for projection

For measurement, each slide was projected onto a white wall with a standard projector having an adjustable focal-length lens (range $=102-152 \mathrm{~mm}$ ) with $\mathrm{f}=3.5$. The distance from the projector to the wall was approximately $6.5 \mathrm{~m}$. The final distance and the size of the focused image were adjusted until a slide containing a $1 \mathrm{~cm}$ bar produced a projected image of $50 \mathrm{~cm}$.

A measuring $\mathrm{T}$-square having a transparent plastic, unmarked edge was marked to measure the three body parts. Since the projected image was 50 times larger than the original, a wing length of $9 \mathrm{~mm}$ had a projected length of $45 \mathrm{~cm}$. The markings placed on the rule corresponded directly to lengths of body parts. Thus, in the fore-wing length range, the actual distance on the rule of $40 \mathrm{~cm}$ to $50 \mathrm{~cm}$ was labeled as 8.0 to $10.0 \mathrm{~mm}$. The scale was subdivided with marks in actual units of $1 \mathrm{~mm}$ which corresponded to wing-length units of $0.02 \mathrm{~mm}$. For measuring partial hind-wing lengths, the rule distance of 19 to $24 \mathrm{~cm}$ was labeled as 3.8 to $4.8 \mathrm{~mm}$. For measuring femur lengths, the rule distance of 11 to $14 \mathrm{~cm}$ was labeled as $2.2 \mathrm{~mm}$ to $2.8 \mathrm{~mm}$. These conversions are illustrated in Fig. 2. This projection system permitted measurements to an accuracy of $0.01 \mathrm{~mm}$. The distances measured on the three body parts are shown in Fig. 3. 


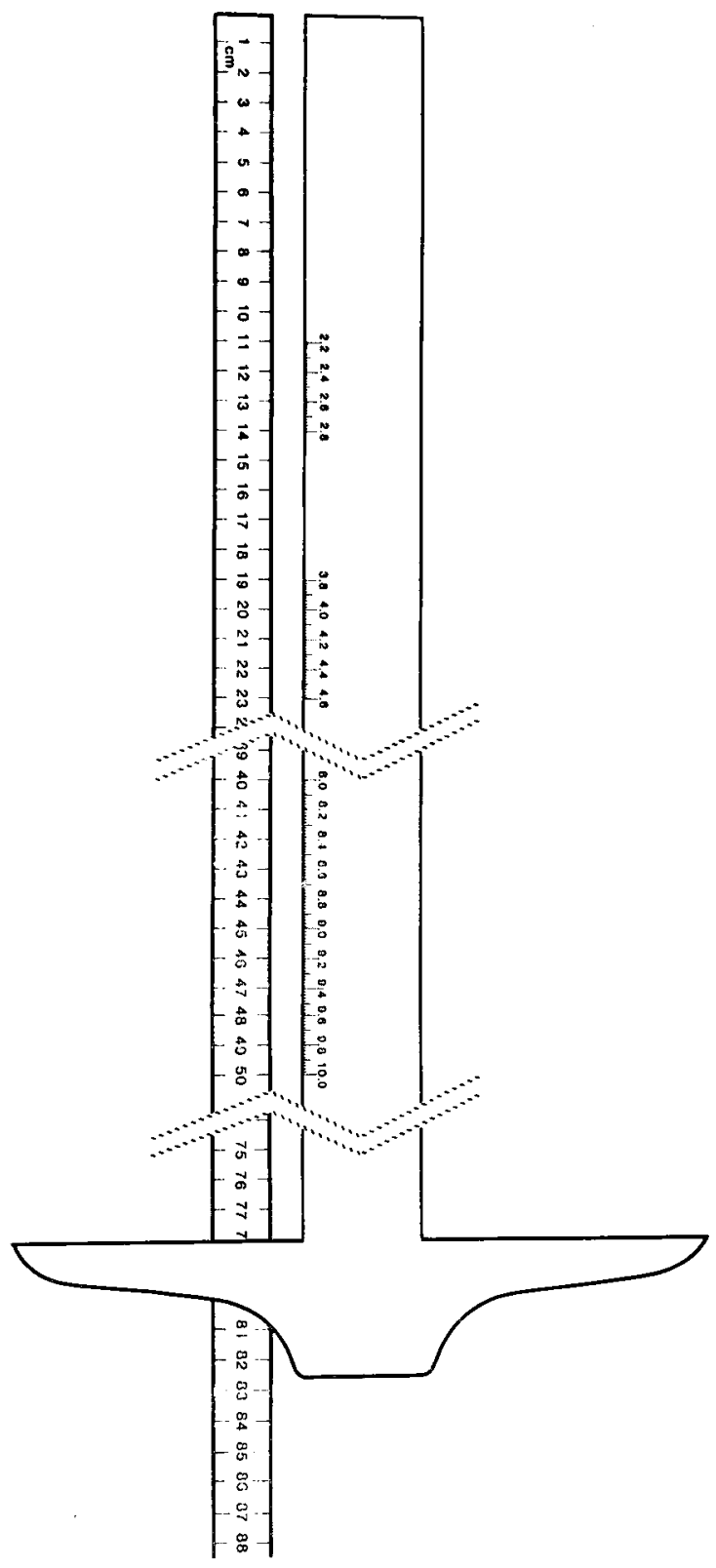

FIG. 2. - The transfer of actual measures of a meter ruter to a T-square marked to read actual body-part lengths in $\mathrm{mm}$ 


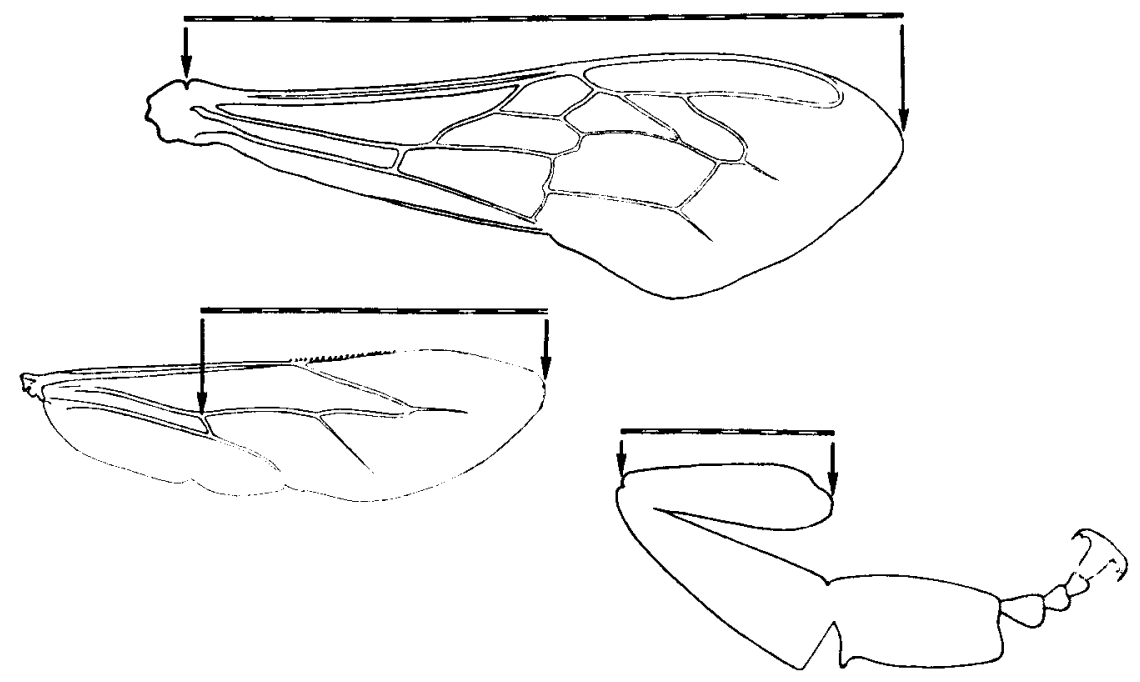

FIG. 3. - The distances measured on fore-wings, hind-wings and femurs

The 100 samples of bees were treated as blind samples and identified. The univariate fore-wing analysis was used first. When an identification was not made at $P>0.95$ the 4-character procedure was used. Different people each made 20 identifications of randomly chosen colonies. These persons ranged from a beekeeper unskilled in laboratory techniques, who received 15 minutes training in the procedure, to research technicians and one scientist having from 1 to 20 years experience making laboratory measurements.

Calculations for identification were made using a * Basic $»$ language program*.

\section{Results}

Overall, the fore-wing procedure correctly identified $81 \%$ of the samples at $P>0.95$ (Table 4). This included 74 and $88 \%$ of the Africanized and European samples, respectively. The remaining 19 samples were unidentified. When these samples were submitted to the multivariate procedure, 12 of them were correctly classified and 7 remained unclassified (Table 4). Had we used P $>0.90$, 5 colonies would have remained unclassified and all classifications would have been correct. Of the 5 unclassified colonies, 3 were European and 2 were Africanized. The closest case of a misclassification was one European colony that was assigned a $P A$ of 0.81 . The next closest case was a European colony that was assigned a $P A$ of 0.41 .

(3) Copies of the program are available upon request. 
TABL. 4. - Number (and percentage) of Africanized (A), European (E) and unclassified $(U)$ samples of a collection of $50 \mathrm{~A}$ and $50 \mathrm{E}$ colonies identified at $P>0.95$ as a test of 2 discriminant-analysis procedures

\begin{tabular}{c|c|c|c|c|c|c}
\hline $\begin{array}{c}\text { Bee } \\
\text { type }\end{array}$ & \multicolumn{3}{|c|}{$\begin{array}{c}\text { Classification } \\
\text { by fore-wing procedure }\end{array}$} & \multicolumn{2}{c}{$\begin{array}{c}\text { Classification by sequential fore-wing } \\
\text { and multivariate procedure }\end{array}$} \\
\cline { 2 - 7 } & $\mathrm{A}$ & $\mathrm{E}$ & $\mathrm{U}$ & $\mathrm{A}$ & $\mathrm{E}$ & $\mathrm{U}$ \\
\hline $\mathrm{A}$ & $\begin{array}{c}37(74.0) \\
0\end{array}$ & $\begin{array}{c}0 \\
\mathrm{E}\end{array}$ & $\begin{array}{r}13(26.0) \\
6(88.0)\end{array}$ & $\begin{array}{c}46(92.0) \\
0\end{array}$ & $\begin{array}{c}0 \\
47(94.0)\end{array}$ & $\begin{array}{c}4(8.0) \\
3(6.0)\end{array}$ \\
\hline
\end{tabular}

\section{DISCUSSION}

Most identification needs can be met with these procedures. A large majority of colonies can be correctly identified at probability levels that meet U.S. federal standards for regulatory action (STIBICK, 1984). Where necessary, samples from the remaining colonies can be submitted to the procedures of DALY and Hoelmer (1985) and Daly et al. (1982). The numbers of such samples would be sufficiently low that one or two central identification laboratories could provide a reasonably rapid response in support of regulatory activities.

DALY and HoELmer (1985) discuss three examples of abnormally small European bees which would be classified as Africanized by our fore-wing analysis and probably by our multivariate analysis. Of these three samples, one came from an experiment where bees were starved, the second was a selected collection of small bees sometimes seen in European colonies and thought to arise as a consequence of being reared in the occasional « half-depth cells found in areas of comb irregularity, and the third came from a colony suspected of showing a generalized dwarfing genetic effect. Additionally, three known mutant alleles, diminutive, short, and truncate, produce bees having unusually short wings (TUCKER, 1985). In all but the case of the dwarfing effect, the wings of these bees are nearly 3 standard deviations shorter than the average of Africanized bees reported by DALY and BALLING (1978). Encountering such extreme samples would be rare. Where they are encountered, especially where a single identification of an Africanized colony is considered an important event, colony observation by an experienced beekeeper capable of identifying severe nutritional stress and additional sampling for a complete morphometric analysis should provide a correct identification. Severe nutritional stress and mutant wing shapes are obvious and bees showing the generalized dwarfing effect will be identified as European by the complete morphometric analysis (DALY and HoElmEr, 1985). 
European bees reared by Africanized bees on Africanized comb would be unidentified by the fore-wing procedure alone. On average they would be assigned a $P E$ of 0.70 (RINDERER et al., 1985 a). The 4 character multivariate analysis assigns them a $P E$ of 0.99 . Africanized bees reared by European bees on European comb would be correctly classified by the wing-length procedure with a $P A$ of 0.98 .

Of the collection of samples from colonies used to develop the discriminant functions (base-line collection) $12.5 \%$ remained unclassified when the procedures were used on them. The second collection (test collection) would be expected to have a somewhat higher percentage of unclassified samples because of the independence of the sample. However, the second collection only had $7 \%$ unclassified samples. This higher level of identification may result from the measurement system. The base line collection was measured according to the computerized system of DALY et al. (1982). The test collection was measured with the projection system described. Perhaps the additional magnification resulted in more accurate measurement which caused the test results to be better than predicted.

The usefulness of these procedures for identifying Africanized and European bees from populations other than those supplying the base-line and test collections is clear from an inspection of data presented by DALY and BALLing (1978). In all cases, their values for measurements of Africanized bees are smaller than those that we used to develop these discriminant analyses. Their values for European bees are similar to ours. Since their samples represent a sampling from a variety of Africanized and European populations, comparison of our values with theirs suggests two features of these identification procedures. First, these procedures will accurately identify samples from several populations of Africanized and European bees. Second, these procedures are relatively conservative; only clearly Africanized bees will be identified as such. Samples of Africanized bees which are more difficult to identify will be unclassified.

The collection, measurement, and analysis procedures are relatively straightforward. Most people probably can do them without difficulty. However, a few points of potential difficulty exist. The ideal bees to collect are those that have recently emerged as adults since they are more likely to arise from eggs laid by the current queen of the colony and certainly are not bees that have drifted to the colony. However, collecting such bees is time consuming and requires beekeeping and bee selection skills. Collecting returning foragers or guard bees is easier. Only where queens in the colony have recently changed or where conditions have caused excessive drifting or robbing will collections of foragers and guards potentially lead to misidentifying the colony. The major difficulty with collecting foragers and guards is that they must be processed to remove pollen pellets, nectar loads and rectal contents. This processing must be done carefully so that the haemo- 
lymph and portions of the digestive tract are not also removed. Persons processing samples should first practice the procedures with known samples of bees until the final weight of their average 10-bee sample is between 0.8 and $1.2 \mathrm{~g}$ for European bees and between 0.6 and $0.9 \mathrm{~g}$ for Africanized bees. Grossly inaccurate weights may lead to misidentifications. European bees with most of their abdominal contents removed may be misidentified as Africanized. Africanized bees having nectar-sacs and rectums filled with nectar and feces may be misidentified as European.

A second potential source of difficulty is the separation of the femur from the trochanter. The proximal end of the femur has an extension which is externally covered by the distal end of the trochanter. This extension must not be separated from the rest of the femur since it is part of the femur measurement (Fig. 4).

Accurate calibration of the measurement system is also important. An inaccuracy of $0.18 \mathrm{~mm}$ in calibration could lead to misclassification (see Table 2). An accurate standard, mounted on a slide, must be used to initially calibrate the projection system and periodically used to ensure continued accuracy. Optical micrometers of various types would be suitable for this purpose. We have used the measurement grids from 2 different brands of «pocket comparators » with success. Others have used etched glass reticles.

A large proportion of samples are correctly identified by these procedures and the probability of a misidentification, assuming that the characters measured have normal distributions, is zero. This is true even for the European bees reared by Africanized bees in Africanized comb and Africanized bees reared by European bees in European comb studied by RindERER et al. (1985 a). These results are surprising, considering the conclusions of PAGE and ERICKSON (1985). Using computer simulation with models having an array of assumptions, they assessed the potential identification power of 3 hypothetical alleles. They concluded that the correct identification of colonies could only occur if 3 conditions were met : « extreme numerical or mating advantage of Africanized drones; low levels of gene flow from the commercial populations into the feral populations; and extreme initial gene frequency differences between commercial and feral populations at the loci used for classification $\gg$.

Apparently, either some of their model assumptions were incorrect, the conditions they considered to be unlikely do occur, or the genetic events underlying the characters measured in even simplified morphometric analysis are considerably more complex and taxonomically assessable than the hypothetical 3 independent alleles. More information is accumulating that the first condition is correct (Rinderer et al., $1985 \mathrm{~b}$; Rinderer, unpublished). If the first condition is correct, the second is likely also to be correct. The variety of morphological studies (loc. cit.) all suggest that the third condition is correct. 
Certainly, the identification of Africanized and European bees in support of regulatory and certification programs is possible with these and other morphometric techniques in areas where Africanized bees now exist. The complete morphometric procedure has had continued validity as the area of Africanization has expanded. It and techniques such as those presented have a high likelihood of continued usefulness as the Africanized population continues to expand.

Received for publication in July 1985. Accepted for publication in October 1985.

\section{ACKNOWLEDGEMENT}

In cooperation with the Louisiana Agricultural Experiment Station.

\section{RESUME \\ TECHNIQUES DE TERRAIN ET METHODES SIMPLIFIEES POUR IDENTIFIER LES ABEILLES AFRICANISEES ET LES ABEILLES EUROPEENNES}

Il est possible de distinguer sur le terrain les types géographiques africanisé et européen s'ils construisent leur propre rayon. D'après la mesure de la distance entre 10 cellules d'ouvrières, répétée trois fois, on peut identifier les colonies ayant des rayons de $4,9 \mathrm{~cm}$ ou moins comme étant africanisées et celles qui ont des rayons de $5,2 \mathrm{~cm}$ ou plus comme étant européennes. Les quelques colonies qui ont des valeurs intermédiaires ne sont pas identifiables, mais probablement africanisées dans une certaine mesure.

L'analyse discriminante des caractères morphométriques peut être utilisée pour identifier les abeilles qui ne produisent pas leur propre rayon. DaLY et coll. ont mis au point des analyses sophistiquées sur ordinateur pour traiter de nombreuses mesures et faire l'analyse discriminante. En s'appuyant sur leurs résultats, on a développé 2 analyses discriminantes simplifiées pour l'utilisation sur le terrain.

La procédure la plus simple n'utilise que la mesure de la longueur de l'aile antérieure de 10 abeilles. Si l'on prend comme critère la probabilité d'une détermination correcte $(P)$ supérieure à $0,90,109$ des 86 colonies africanisées et des 50 colonies européennes du Vénézuela (soit $86 \%$ ) sont correctement identifiées. Aucun échantillon n'a été mal identifié mais les échantillons restants ont été non identifiés, A P $>0,95$ et $\mathrm{P}>0,99,69 \%$ et $52 \%$ ont été respectivement identifiés correctement. Les formules et les constantes pour l'analyse son indiquées.

En ajoutant des caractères supplémentaires, on obtient des améliorations substantielles dans le pouvoir discriminatoire, mais au prix d'un coût en temps et en équipement. Le meilleur ensemble multivariable comporte les mesures de la longueur de l'aile antérieure, de la longueur partielle de l'aile postérieure, de la longueur du fémur et du «poids net » (poids des ouvrières après élimination des fécès et du contenu du jabot). Avec cette analyse, $91 \%$ des échantillons ont été correctement identifiés à $\mathbf{P}>0,90$ et aucun échantillon n'a été mal identifié. L'analyse discriminante multivariable est quelque peu complexe et se fait probablement mieux avec une calculatrice programmable ou un ordinateur.

Les mesures nécessaires et les procédés pour les réaliser sont illustrés et décrits. On discute ces procédés testés sur un échantillon indépendant de 50 colonies africanisées et 50 colonies européennes. Les problèmes susceptibles d'être rencontrés au cours des mesures sont : élimination des fécès et du contenu du jabot pour obtenir le «poids net», séparation du fémur du trochanter et étalonnage du système de mesure. 


\title{
ZUSAMMENFASSUNG
}

\author{
FEIDDETHODEN UND VEREINFACHTE VERFAHREN \\ ZUR BESTIMMUNG AFRIKANISIERTER UND EUROPAISCHER HONIGBIENEN
}

Bienen afrikanisierter und europäischer Herkunft können im Feld voneinander unterschieden werden, wenn sie ihre eigenen Waben gebaut haben. Auf Grund von drei Messungen von Zeilen mit 10 Arbeiterzellen wurden Waben mit einer Länge dieser Strecke von $4.9 \mathrm{~cm}$ oder weniger als afrikanisiert bestimmt, solche mit einem 10-Zellenmaß von $5.2 \mathrm{~cm}$ oder mehr als europäisch. Die wenigen Völker mit Maßen, die zwischen diesen beiden Werten liegen, können nicht klassifiziert werden, aber sie sind wahrscheinlich zu einem gewissen Grad afrikanisiert.

Zur Bestimmung von Bienen, die keinen eigenen Wabenbau errichtet haben. können Diskriminanzanalysen von morphometrischen Merkmalen herangezogen werden. DALY und seine Mitarbeiter haben ausgefeilte Analysen unter Einsatz eines Computers entwickelt, um viele Messungen in Diskriminanzanalysen auszuwerten. Auf ihren Ergebnissen aufbauend wurden zwei vereinfachte Diskriminanzanalysen für den Einsatz in der Praxis entwickelt.

Das einfachste Verfahren benutzt lediglich die Länge des Vorderflügels von 10 Bienen. Wird als Bewertungsgrundlage die Wahrscheinlichkeit einer richtigen Bestimmung (P) von mehr als 0.90 angenommen, dann wurden 109 von 86 afrikanisierten und 50 europäischen Völkern in Venezuela korrekt bestimmt $(=86 \%)$. Keine cinzige Probe wurde falsch eingestuft, aber der Rest der Proben blieb unbestimmt. Bei einem $\mathbf{P}$ von $>0,95$ und $\mathbf{P}>0,99$ wurden $69 \%$ bzw. $52 \%$ korrekt bestimmt. Die Formeln und Konstanten für die Analyse werden mitgeteilt.

Eine wesentliche Verbesserung der Unterscheidungsmöglichkeit wird durch Verwendung mehrerer Merkmale erzielt, jedoch nur auf Kosten eines höheren Aufwandes an Zeit und Ausrüstung. Der beste Multivariat-Satz beruhte auf Messungen der Vorderflügellänge, einer Teillänge des Hinterflügels, der Länge des Femur und des «Reingewichts» der Biene (Körpergewicht nach Entleerung von Kotblase und Honigsack). Bei dieser Analyse wurden $91 \%$ der Proben auf einem Wahrscheinlichkeitsniveau von $\mathbf{P}>0,90$ korrekt bestimmt, ohne Fehlbestimmung einer Probe. Diese multivariate Diskriminanzanalyse ist etwas komplex und am besten mit einem programmierbaren Taschenrechner oder einem Computer auszuführen. Die Formeln und die Art der Durchführung werden angegeben.

Die benötigten Messungen und ihre Durchführung werden abgebildet und beschrieben. Ein Test dieser Methode an einer unabhängigen Probe von 50 afrikanisierten und 50 europäischen Völkern wird diskutiert. Die Probleme, auf die man möglicherweise bei der Durchführung dieses Verfahrens stößt, sind folgende : Entfernung der Fäzes und des Honigsack-Inhalts um das «Reingewicht 》 zu erhalten, Ablösung des Femur vom Trochanter und Bestimmung des Vergrößerungsmaßstabes.

\section{BIBLIOGRAPHY}

Carlson D.A., Bol.ten A.B., 1984. - Identification of Africanized and European honey bees using extracted hydrocarbons. Bull. Entomol. Soc. Amer., 30, 32-35.

Daly H.V., Balling S.S., 1978. - Identification of Africanized honeybees in the Western Hemisphere by discriminant analysis. J. Kansas Entomol. Soc., 51, 857-869.

Daly H.V., Hoelmer K., 1985. - Rapid identification of Africanized honeybees by morphometric analysis. In preparation.

Daly H.V., Hoelmer K., Norman P., Allen T., 1982. - Computer-assisted measurement and identification of honey bees (Hymenoptera : Apidae). Ann. Entomol. Soc. Amer., 75, 591-594. 
GARY N.E., LORENZEN K., 1976. - A method for collecting the honey-sac contents from honeybees. J. Apic. Res., 15, 73-79.

Page R.E.Jr., Erickson E.H.Jr., 1985. - Identification and certification of Africanized honey bees. Ann. Entomol. Soc. Amer., 78, 149-158.

Rinderer T.E., TUCKer K.W., Collins A.M., 1982. - Nest cavity selection by swarms of European and Africanized honeybees. J. Apic. Res., 21, 98-103.

Rinderer T.E., Sylvester H.A., Colluns A.M., Pesante D., 1985 a. - Effect of nurse-bee genotype and comb size on morphometrically based identification of Africanized and European honey bees. Bull. Entomol. Soc. Amer. In press.

Rinderer T.E., Hellmich R.L. II. Danka R.G., Collins A.M., 1985 b. - Male reproductive parasitism : A factor in the Africanization of European honey-bee populations. Science, 228, $1119-1120$.

SAS, 1982. - SAS User's Guide : Statistics. SAS Institute Inc., Cary, North Carolina.

Stibick J.N.L., 1984. - Animal and Plant Health Inspection Service strategy and the African Honey Bee. Bull. Entomol. Soc. Amer., 30, 22-26.

Sylvester H.A., 1982. - Electrophoretic identification of Africanized honeybees. J. Apic. Res., 21, 93-97.

TUCKer K.W., 1985. - Visible mutants. In : RINDERER T.E., ed. Bee Genetics and Breeding, Academic Press Inc., New York. In press. 